\title{
SISTEM PEMESANAN MAKANAN TRADISIONAL BERBASIS ANDROID MENGGUNAKAN METODE HAVERSINE FORMULA
}

\author{
Dzakaul Malik $^{1}$, Vidila Rosalina ${ }^{2}$ \\ Jurusan Teknik Infomatika FTI Universitas Serang Raya \\ Jalan Raya Serang, Cilegon KM. 5 Taman Drangong Serang \\ 1Dzakaul_01@gmail.com \\ 2 vidila.suhendarsah@ @ gmail.com
}

\begin{abstract}
Abstrak- Penerapan metode haversine formula peda penelitian ini digunakan untuk menghitung jarak antara penjual dan pemesan dengan memanfaatkan sensor geolocation pada smartphone android. Perancangan sistem ini menggunakan UML (Unified Model Language). Pengembangan sistem pemesanan makanan tradisional di Kabupaten Pandeglang Provinsi Banten ini berbasis android. Hasil aplikasi pada penelitian ini digunakan untuk membantu penjual makanan tradisional di Kabupaten Pandeglang mempromosikan makanan tradisional yang mereka jual serta meningkatkan retensi pelanggannya dengan memberi kemudahan para pembeli untuk mendapatkan informasi dan memesan makanan tradisional di Kabupaten Pandeglang.
\end{abstract}

Kata Kunci : Haversine Formulla, Smartphone Android, Pemesanan Makanan, Makanan Tradisional, Kabupaten Pandeglang

\section{PENDAHULUAN}

Seiring perkembangan zaman, teknologi berkembang sangat pesat. Banyak media informasi yang didapat dari teknologi melalui internet maupun aplikasi. Internet adalah salah satu media informasi yang sangat luas, sehingga banyak pengguna yang memanfaatkan internet sebagai media untuk mendapatkan informasi. Survei yang dilakukan oleh Asosiasi Penyelenggara Jaringan Internet Indonesia (APJII) sepanjang tahun 2016 menyatakan bahwa 132,7 juta orang telah terhubung ke internet (sumber: Buletin APJII Edisi 05 November 2016). Selaras dengan hal itu, penggunaan internet untuk mempromosikan usaha memiliki peluang yang cukup besar. Dalam dunia usaha, baik perusahaan maupun sektor lainnya dituntut untuk melakukan inovasi yang menarik pelanggan dengan memanfaatkan internet untuk membuat situs yang dapat melayani pemesanan secara online .

Dunia komputer dan perangkat-perangkat lainnya sudah bukan lagi menjadi sesuatu yang asing. Sebut saja misalnya handphone, laptop, notebook dan mobile device. Hampir semua orang dari berbagai kalangan sudah mengenal istilahistilah tersebut saat ini. Hingga akhirnya pihak pengembangpun semakin berlomba-lomba untuk mengembangkan teknologi yang sudah ada sehingga memungkinkan masyarakat untuk dapat memanfaatkan teknologi tersebut untuk mempermudah pekerjaannya, ataupun memanfaatkannya untuk memenuhi kebutuhan lifestyle dan lainnya. Kemudahan dan efisiensi menjadi titik tumpu utama dalam pengembangan teknologi-teknologi tersebut.

Dalam penelitian ini, penulis melibatkan usaha-usaha makanan tradisional yang berada di Kabupaten Pandeglang. Selain untuk melayani pemesanan, penulis juga ingin mempromosikan makanan tradisional khas Pandeglang, karena banyak sekali makanan tradisional Pandeglang yang belum banyak diketahui bahkan oleh masyarakat Pandeglang sendiri.

Pada saat ini, usaha-usaha makanan tradisional di kabupaten Pandeglang masih menggunakan cara manual untuk pemesanan makanan yaitu dengan mendatangi langsung tempat usaha makanan tradisional tersebut.

Penerapan haversine formulla pada penelitian sehingga pelanggan dapat mengetahui jarak dan waktu saat melakukan pemesanan makanan tradisional di Kabupaten Pandeglang.

Aplikasi yang dibuat pada penelitian ini berbasis smartphone android, karena hampir 
semua orang kini menggunakan smartphone sehingga usaha-usaha makanan tradisional di kabupaten Pandeglang dapat mempromosikan makanan tradisional dan masyarakat di kabupaten Pandeglang dapat melakukan pemesanan makanan

\section{METODOLOGI PENELITIAN}

Haversine Formula adalah sebuah persamaan yang penting dalam bidang navigasi, untuk mencari jarak busur antara dua titik pada bola dari longitudedan latitude. Ini merupakan bentuk persamaan khusus dari trigonometri bola, law of haversines, mencari hubungan sisi dan sudut pada segitiga dalam bidang bola.Formula ini pertama kali ditemukan oleh Jamez Andrew di tahun 1805, dan digunakan pertama kali olehJosef de Mendoza y Ríos di tahun 1801. Istilah haversine ini sendiri diciptakan pada tahun 1835 oleh Prof. James Inman. Josef de Mendoza y Ríos menggunakan haversinep ertama kali dalam penelitiannya untuk menemukan jarak antar bintang. Haversine Formula nantinya akan digunakan dalam perhitunngan jarak antara dua titik GPS. Dalam hal ini adalah titik GPS user dan titik GPS tujuan, titik GPS ini berisikan latitude dan longitude, sehingga dapat menjadi kunci utama dalam perbandingan jarak pada penentuan lokasi terdekat. Berikut rumus Haversine yang akan pada penelitian ini:

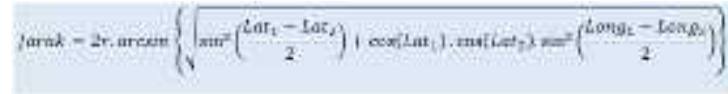

Waterfall Model adalah sebuah metode pengembangan software yang bersifat sekuensial. Metode ini dikenalkan oleh Royce pada tahun 1970 dan pada saat itu disebut sebaga isi klus klasik dan sekarang ini lebih dikenal dengan sekuensial linier. Selain itu model ini merupakan model yang paling banyak dipakai oleh para pengembang software. Inti dari metode waterfall adalah pengerjaan dari suatu sistem dilakukan secara berurutan atau secara linear. Jadi jika langkah satu belum dikerjakan maka tidak akan bisa melanjutkan kelangkah 2, 3 dan seterusnya. Secara otomatis tahapan ke-3 akan bisa dilakukan jika tahap ke-1 dan ke-2 sudah dilakukan.

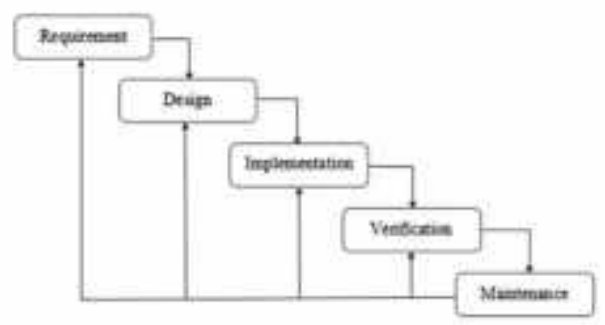

Gambar 2.1 Waterfall Model tradisional melalui smartphone android, yang diharapkan mampu membantu penjual dalam mempromosikan makanan tradisional dan pembeli dalam pemesanan makanan.

\section{Sumber:}

http://www.pengetahuandanteknologi.com/2 016/09/metode-waterfall-definisi-

tahapan.html

Keterkaitan dan pengaruh antar tahap ini ada karena output sebuah tahap dalam Waterfall Model merupakan input bagi tahap berikutnya, dengan demikian ketidak sempurnaan hasil pelaksanaan tahap sebelumnya adalah awal ketidak sempurnaan tahap berikutnya. Memperhatikan karakteristik ini, sangat penting bagi tim pengembang dan perusahaan untuk secara bersama-sama melakukan analisa kebutuhan dan desain sistem sesempurna mungkin sebelum masuk kedalam tahap penulisan kode program. Secara garis besar metode waterfall mempunyai langkah-langkah sebagai berikut : [1]. Analisa Kebutuhan, langkah ini merupakan analisa terhadap kebutuhan sistem.Pengumpulan data dalam tahap ini bisa melakukan sebuah penelitian, wawancara atau study literatur. Seorang system analis akan menggali informasi sebanyakbanyaknya dari user sehingga akan tercipta sebuah system komputer yang bisa melakukan tugas-tugas yang diinginkan oleh user tersebut. Tahapan ini akan menghasilkan dokumen user requirement atau bisa dikatakan sebagai data yang berhubungan dengan keinginan user dalam pembuatan sistem. Dokumen inilah yang akan menjadi acuan system analis untuk menterjemahkan ke dalam bahasa pemprograman. [2]. Desain Sistem, Proses desain akan menerjemahkan syarat kebutuhan kesebuah perancangan perangkat lunak yang dapat diperkirakan sebelum dibuat coding. Proses ini berfokus pada struktur data, arsitektur perangkat lunak, representasi interface, dan detail (algoritma) prosedural. Tahapan ini akan menghasilkan dokumen yang disebut software requirment. Dokumen inilah yang akan digunakan programmer untuk melakukan aktivitas pembuatan sistemnya. [3]. Coding dan Testing, Coding merupakan penerjemahan design dalam bahasa yang bisa dikenali oleh komputer. Dilakukan oleh programmer yang akan menterjemahkan transaksi yang diminta oleh user. Tahapan inilah yang merupakan tahapan secara nyata dalam mengerjakan suatu sistem. Dalam artian penggunaan komputer akan dimaksimalkan dalam tahapan ini. Setelah pengkodean selesai maka akan dilakukan testing terhadap sistem yang telah dibuat tadi. Tujuan testing adalah menemukan kesalahankesalahan terhadap system tersebut dan kemudian bisa diperbaiki. [4]. Pengujian Sistem, Tahapan ini 
bisa dikatakan final dalam pembuatan sebuah system. Setelah melakukan analisa, design dan pengkodean maka sistem yang sudah jadiakan digunakan oleh user. [5]. Pemeliharaan, Perangkat lunak yang sudah disampaikan kepada pelanggan pasti akan mengalami perubahan. Perubahan tersebut bisa karena mengalami kesalahan karena perangkat lunak harus menyesuaikan dengan lingkungan (periperal atau system operasi baru), atau karena pelanggan membutuhkan perkembangan fungsional.

\section{HASIL DAN PEMBAHASAN}

Implementasi merupakan tahap untuk mengembangkan rencana rancangan aplikasi menjadi aplikasi yang seutuhnya. Pengembangan tersebut tentunya dilakukan dengan menulis kodekode program ke dalam sebuah aplikasi development berbasis java android. Disamping itu disajikan juga tampilan dari Aplikasi setelah di implementasikan di smartphone Android.

\section{Instalasi Pada Gadget Android}

Setelah proses export selesai maka akan menghasilkan file dengan extensi APK, file apk tersebut dimasukkan ke dalam kartu memori gadget untuk melakukan proses instalasi. Proses instalasinya sebagai berikut :

1. Pertama user masuk ke menu Pengaturan pilih Keamanan beri tanda centang $(\sqrt{ })$ pada Sember tidak diketahui, agar smartphone android dapat melakukan instalasi file apk sebagai berikut :

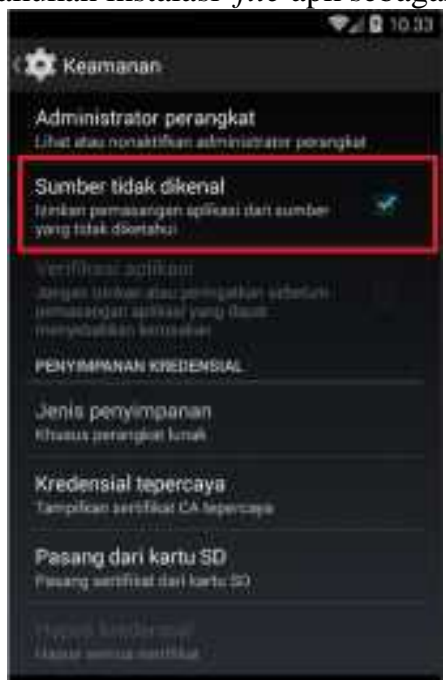

Gambar 1 Mengubah Setting pada Keamanan

Pilih dan ketuk file pemaktra.apk, maka akan muncul halaman instalasi file apk lalu pilih pasang sebagai berikut :

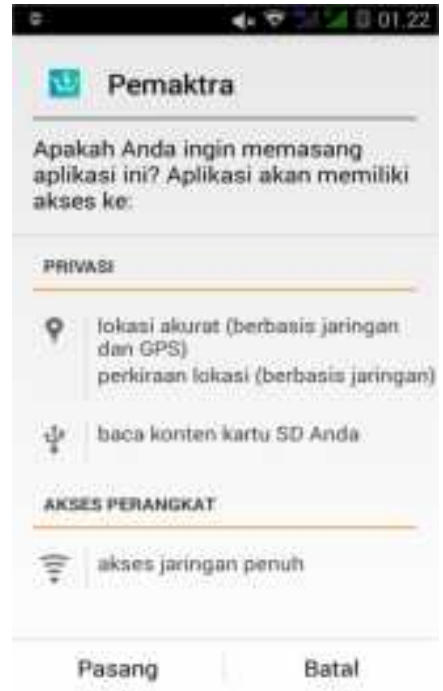

Gambar 2 Proses Pertama Instalasi.

Setelah dipilih menu Pasang maka akan tampil halaman proses instalasi, tunggu sampai prosesnya selesai. Proses instalasinya sebagai berikut :

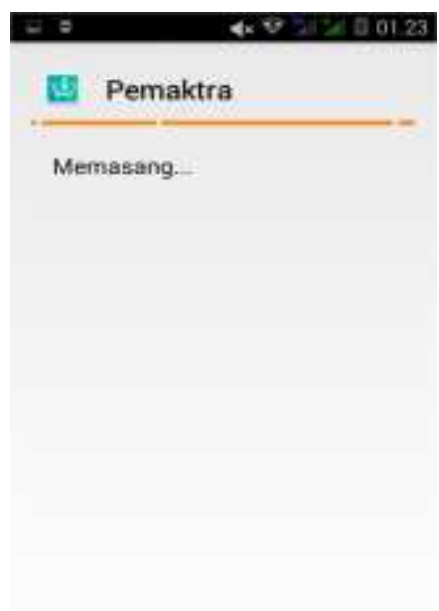

Gambar 3 Proses Instalasi Sedang Berjalan.

2. Setelah proses instalasi selesai, maka akan terdapat aplikasi baru dengan nama Pemaktra. Sebagai berikut : 


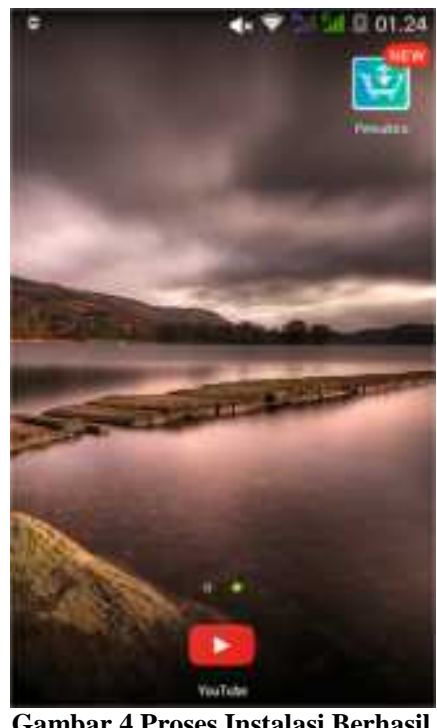

Antarmuka Aplikasi Pada Gadget Android

Antar muka digunakan untuk mempermudah pengguna untuk mengoperasikan aplikasi yang telah dibuat. Berikut ini adalah implementasi antarmuka dari Aplikasi Pemesanan Makanan Tradisional Kabupaten Pandeglang :

\section{Tampilan Splash Screen}

Tampilan Splash Screen merupakan tampilan dimana user pertama kali membuka aplikasi. Tampilan Splash Screen bisa dilihat pada gambar 5 .

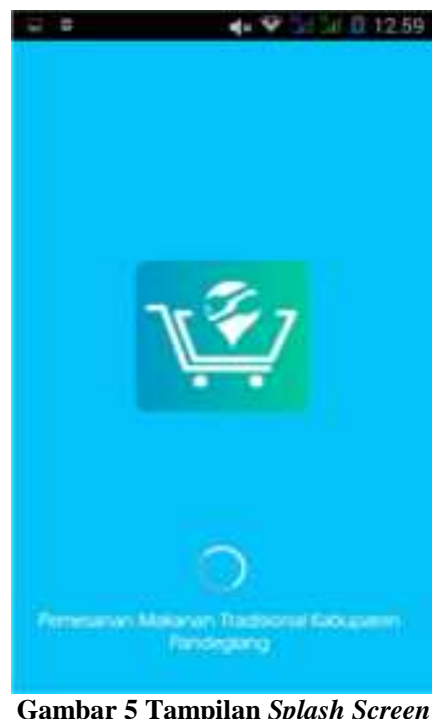

\section{Tampilan Menu Admin}

Tampilan Menu Admin merupakan tampilan list menu user dengan hak akses admin. Tampilan Menu Admin bisa dilihat pada gambar 4.6.

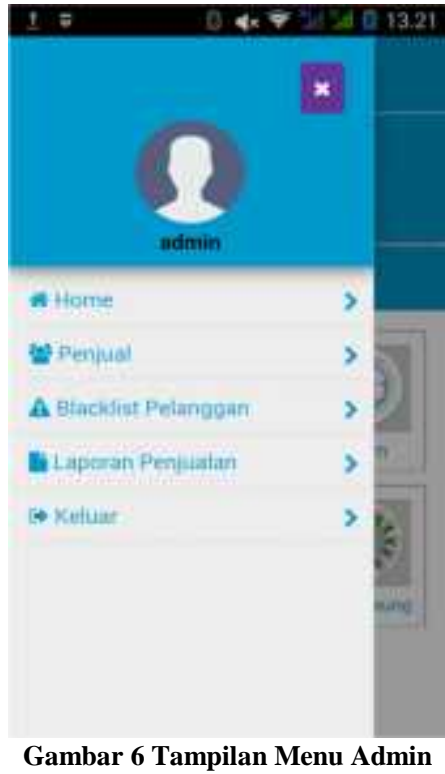

\section{Tampilan Menu Penjual}

Tampilan Menu Penjual merupakan tampilan list menu untuk user yang memiliki hak akses sebagai penjual. Tampilan menu penjual bisa dilihat pada gambar 7 .

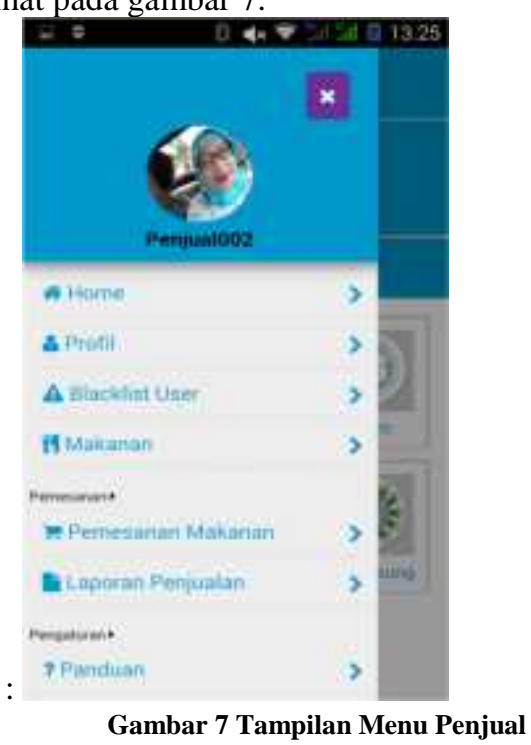

2. Tampilan Menu Pelanggan

Tampilan Menu Pelanggan merupakan tampilan list menu user dengan hak akses pelanggan. Tampilan Menu pelanggan bisa dilihat pada gambar 8 . 


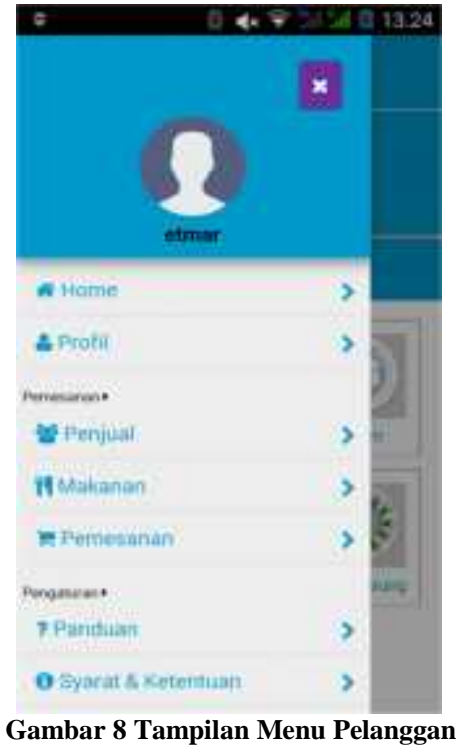

\section{Tampilan Register}

Tampilan Register merupakan tampilan bagi pelanggan untuk melakukan proses pendaftaran. Tampilan Register bisa dilihat pada gambar 9 .

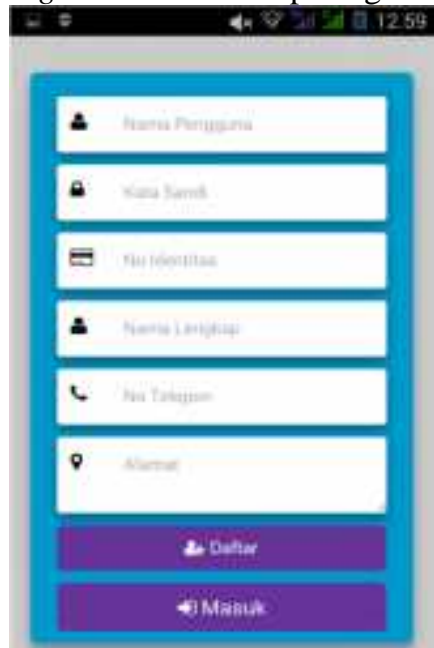

Gambar 9 Tampilan Register

\section{Tampilan Login}

Tampilan Login merupakan tampilan dimana user akan memasukan username dan password. Tampilan Login bisa dilihat pada gambar 10.

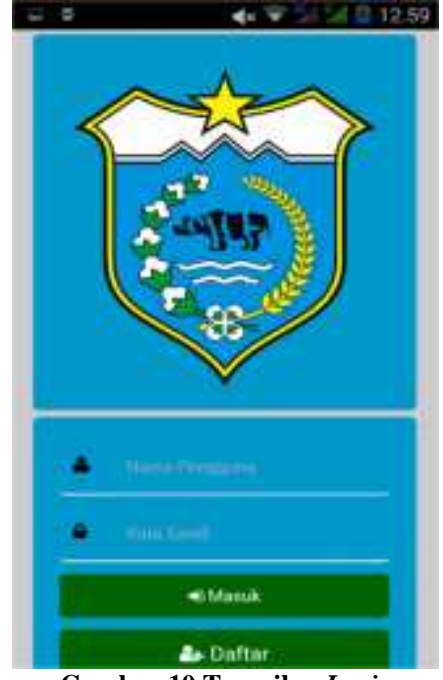

Gambar 10 Tampilan Login

\section{Tampilan Home}

Tampilan Home merupakan tampilan dimana user yang telah melakukan login dan langsung di arahkan ke tampilan Home. Tampilan Home bisa dilihat pada gambar 11 .

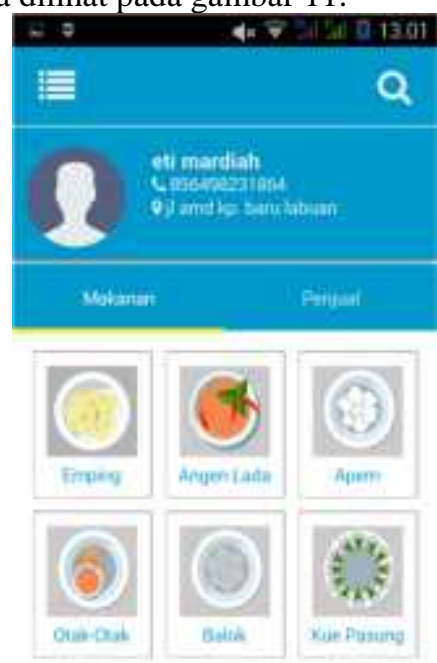

Gambar 11 Tampilan Home

\section{Tampilan Katalog Penjual}

Tampilan Katalog Penjual merupakan tampilan dimana sistem menampilkan list panjual yang sudah tersimpan di database. Tampilan Katalog Penjual bisa dilihat pada gambar 12.

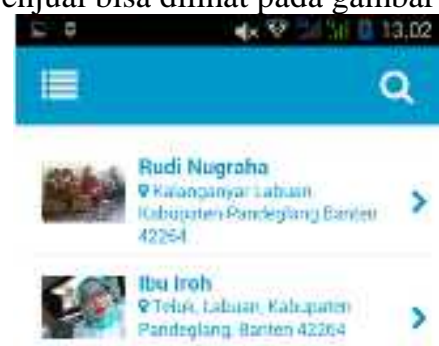

Gambar 12 Tampilan Katalog Penjual

5. Tampilan Detail Penjual 
Tampilan Detail Penjual merupakan tampilan dimana sistem menampilkan informasi detail penjual setelah user menekan atau menyentuh penjual pada katalog penjual. Tampilan Detail Penjual bisa dilihat pada gambar 13.

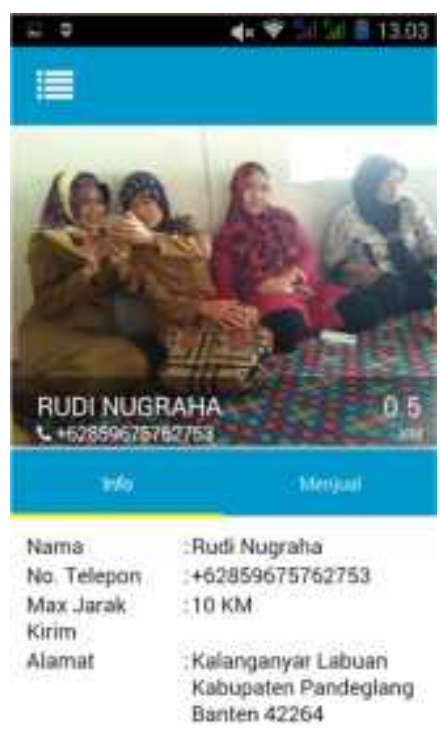

Gambar 13 Tampilan Detail Penjual

\section{Tampilan Katalog Makanan}

Tampilan Katalog Makanan merupakan tampilan dimana sistem menampilkan data-data makanan yang sudah tersimpan di database. Tampilan Katalog Makanan bisa dilihat pada gambar 14 .

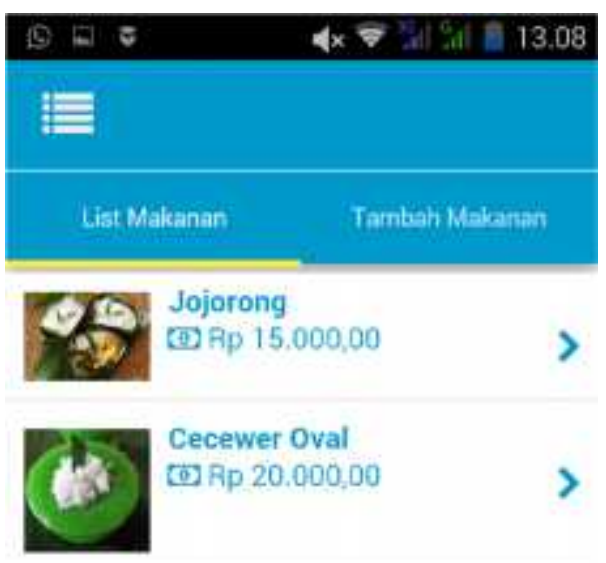

Gambar 14 Tampilan Katalog Makanan

\section{Tampilan Detail Makanan}

Tampilan Detail Makanan merupakan tampilan dimana sistem menampilkan informasi detail makanan setelah user menekan atau menyentuh penjual pada katalog penjual. Tampilan Detail Makanan bisa dilihat pada gambar 15.

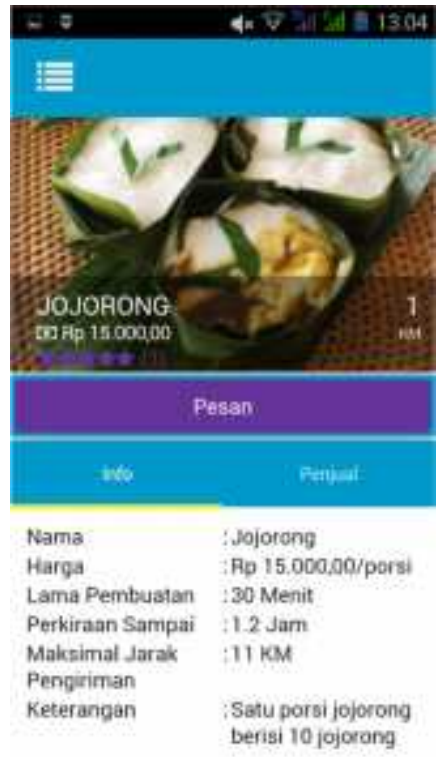

Gambar 15 Tampilan Detail Makanan

\section{Tampilan Form Pemesanan}

Tampilan Form Pemesanan merupakan tampilan dimana user akan memasukan lokasi pengiriman makanan dan jumlah porsi makanan yang akan di pesan, selain itu sistem juga menampilkan peta lokasi pengirim dan lokasi pemesan. Tampilan Form Pemesanan bisa dilihat pada gambar 16 .
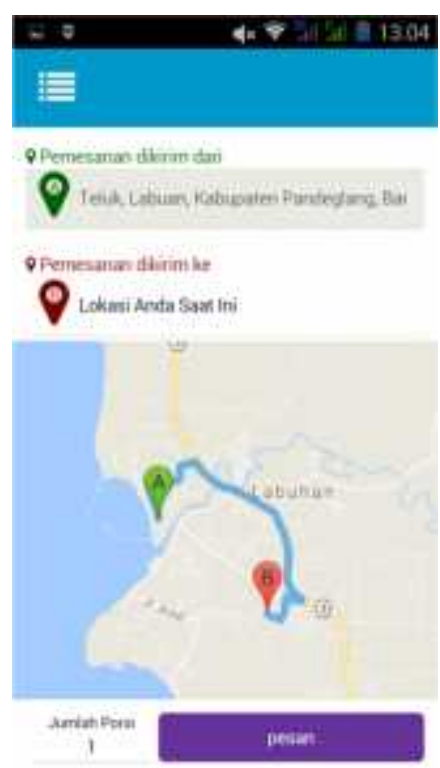

Gambar 16 Tampilan Form Pemesanan Mencari Jarak Terdekat Menggunakan Haversine Formula

6. Tampilan pemesanan Prakonfirmasi

Tampilan pemesanan Prakonfirmasi merupakan tampilan detail pemesanan makanan sebelum di konfirmasi oleh penjual. Tampilan Pemesanan Prakonfirmasi bisa dilihat pada gambar 17. 


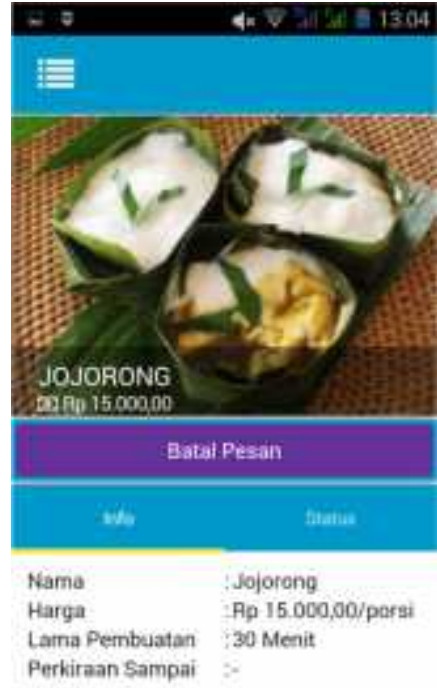

Gambar 17 Tampilan Pemesanan Prakonfirmasi

\section{Tampilan Rating dan Review}

Tampilan Rating dan Review merupakan tampilan dimana user akan memberikan Rating dan Review makanan. Tampilan Rating dan Review bisa dilihat pada gambar 18 .

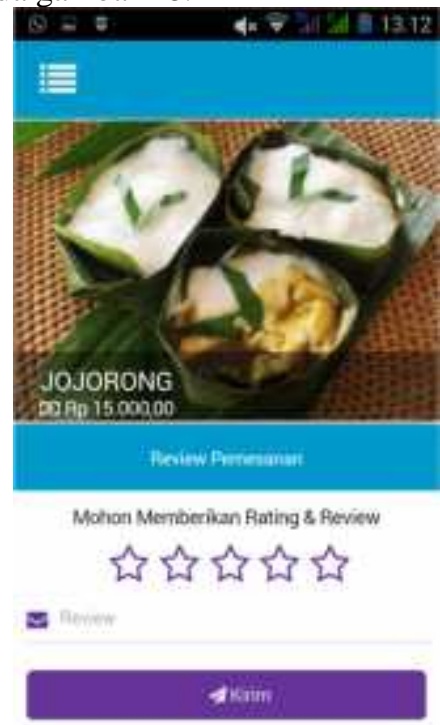

Gambar 18 Tampilan Rating dan Review

\section{Tampilan Panduan}

Tampilan Panduan merupakan tampilan dimana sistem menampilkan informasi panduan penggunaan aplikasi. Tampilan Panduan bisa dilihat pada gambar 19 .

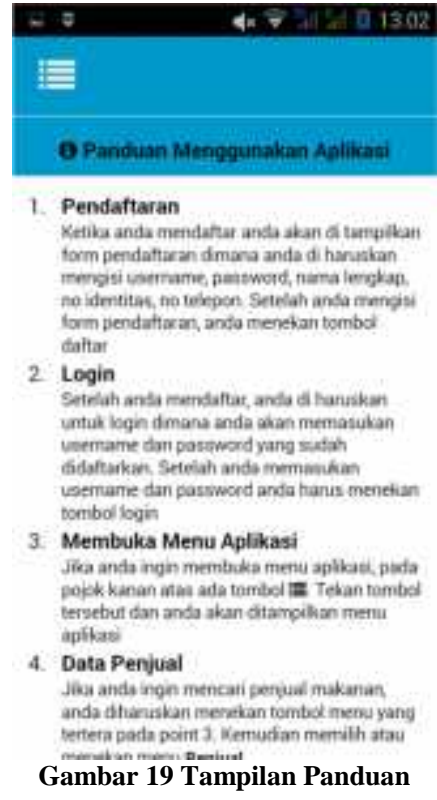

Tampilan Syarat dan Ketentuan

Tampilan Syarat dan Ketentuan merupakan tampilan dimana sistem menampilkan informasi syarat dan ketentuan dalam menggunakan aplikasi. Tampilan Syarat dan Ketentuan bisa dilihat pada gambar 20.

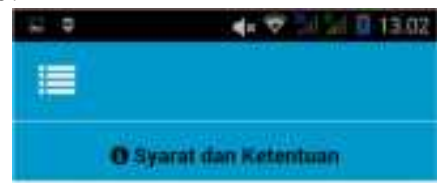

1. Kami akan menyimpan dan

memproses informasi gepertino

identitas, no telepoen dan alamat andia

ketika mendaftar. Anda Harus

memberikan intormasi yang akourat

dan lengkap, memperbaharu

informasi dan setuju untuk

menberikan kepata kami bukt

identitas apapun yang secara wajar

ctapat kami mintakan

2 Anda harya dapat mencgunakan

Aplikasi ketika Anda tefah mendaftar

pada Aplikasi tersebut. Setelah And

berthasil mendaftarkan diri, Aplikatsi

akan memberikan Anda suatu akun

perihadi yang dapat diakses dengan

kata sand yang Anda pilits

3. Harrya Anda yang dapat menggunakar aloun Anda senciri dan Anda berjani untuk tidak memberikan wewenang

Gambar 20 Tampilan Syarat dan Ketentuan

\section{KESIMPULAN}

Dari hasil analisis, perancangan, implementasi dan pengujian aplikasi ini dapat di ambil kesimpulan sebagai berikut:

1. Aplikasi ini dapat mempermudah calon pembeli dengan memberikan informasi penjual makanan tradisional di Kabupaten Pandeglang.

2. Aplikasi ini dapat mempromosikan makanan tradisional di kabupaten pandeglang kepada calon pelanggan.

3. Perancangan sistem dibuat menggunakan metode pengembangan waterfall dan metode Haversine 
Formulla, sehingga aplikasi dapat menghitung jarak dan tibanya makanan ketika pemesanan sedang berlangsung.

4.

\section{REFERENSI}

[1]Abdillah Rizky Muhammad, (2012). Perancangan Aplikasi Media Pemesanan Makanan dan Minuman Berbasis Platform Mobile Android (Studi Kasus: Dapur Runi Cibubur)". Cibubur

[2]Agnes Santoso, Olivia, (2016). Tentang Pengertian Website dan Contohnya. https://oliviaagnez.wordpress.com/2016/02/18/pe ngertian-website-dan-contohnya/. [Diakses 26 Oktober 2017].

[3]Ahaddin Fachrul. (2015). Mengenal Usecase Diagram.

https://www.dumetschool.com/blog/MengenalUse-Case-Diagram. [Diakses 26 Oktober 2017]

[4]Fitho Galandi. (2016). Metode Waterfall: Definisi, Tahapan. http://www.pengetahuandanteknologi.com/2016/ 09/metode-waterfall-definisi-tahapan.html.

[Diakses 26 Oktober 2017]

[5]Inayati, Imah, dkk. (2015). Aplikasi Pemesanan Makanan Berbasis Web (Studi Kasus RM Lesehan Berkah Ilaahi Gresik). Gersik.

[6]Pinaryo Sis, (2015). Aplikasi Pencarian Polsek di Yogyakarta Berbasis Android Menggunakan Metode Haversine. Yogyakarta.

[7]Rifani, Nurhalidah. (2015).Sistem Informasi Pemesanan Makanan Berbasis Webdi Deneira Catering Lembang. Lembang.

[8]Rosalina, Vidila, dkk. (2017). Sosialisasi Pemanfaatan E-CRM untuk Meningkatkan Retensi Pelanggan UMKM . Jurnal Wikrama Parahita Vol 1 No1. November 2017

[9]Rosalina, Vidila, dkk. (2017). Model Electronic Customer Relationship Management (E-CRM) Menggunakan Adaptasi Bahasa Lokal Pada Usaha Mikro Kecil Menengah (UMKM) Banten,
Prosiding SENASSET 2017 (Seminar Nasional Riset Terapan) ISBN 978-602-73672-0-3 : 12, November 2017.

[10]Rosalina, Vidila. (2018). Pemanfaatan Aplikasi E-CRM Dalam Upaya Meningkatkan retensi Pelanggan UMKM, Seminar Nasional SEMBADHA 2018 pada tanggal 17-18 November 2018. Di Sekolah Tinggi Akuntansi Negara (STAN) Bintaro Banten.

[11]Rosalina, Vidila (2019). Electronic Customer Relationship Management (E-CRM) Modeling As Efforts to Increase Customer Retention of Micro Small and Medium Enterprises (MSMEs) in Banten. ICComSET 26-27 November 2018 Tasikmalaya.

[12]Rosalina, Vidila (2019), Electronic Customer Relationship Management (E-CRM) Application as Efforts to Increase Customer Retention of Micro Small and Medium Enterprises (MSMEs) in Banten Indonesia. International Journal of Computer Applications (0975-8887) Volume 182, January 2019

[13]Septian, Rendi, (2011). Tentang Pengertian HTTP, Sejarah HTTP dan Cara Kerja HTTP. http://www.randyseptian.web.id/pengertian-dancara-kerja-http.html. [Diakses 26 Oktober 2017].

[14]Soemartono Kasyfi Henri, Brata Trensa Kusuma, Tim APPJI. (2016). Buletin APJII Edisi 05 November 2016. Jakarta.

[15]Widyatmoko, (2012). Pemanfaatan Geolocation dan Haversine Formulla Dalam Perancangan Sistem Informasi Geografis (Studi Kasus Pariwisata Kabupaten Semarang. Semarang.

[16]Wira Setiawan. (2014). Formulla Haversine. https://wirasetiawan29.wordpress.com/2014/08/1 8/formula-haversine/. [Diakses 26 Oktober 2017]

[17]Wirdada, Syem, Dkk. (2014). Perancangan Sistem Informasi Pemesanan Menu Berbasis Web (Studi Kasus : Coffee Tembalang, Semarang). Semarang 